Hall, Christopher J ORCID:

https://orcid.org/0000-0001-9038-1238 (2000) Prefixation, suffixation and circumfixation. In: Booij, Geert, Lehmann, Christian, Mugdan, Joachim, Kesselheim, Wolfgang and Skopeteas, Stavros, (eds.) Morphology. An international handbook on inflection and word formation. Handbooks of Linguistics and Communication Science (17.1). Berlin, De Gruyter, pp. 535-545

Downloaded from: http://ray.yorksj.ac.uk/id/eprint/2866/

The version presented here may differ from the published version or version of record. If you intend to cite from the work you are advised to consult the publisher's version:

Research at York St John (RaY) is an institutional repository. It supports the principles of open access by making the research outputs of the University available in digital form. Copyright of the items stored in RaY reside with the authors and/or other copyright owners. Users may access full text items free of charge, and may download a copy for private study or non-commercial research. For further reuse terms, see licence terms governing individual outputs. Institutional Repository Policy Statement

\title{
RaY
}

Research at the University of York St John

For more information please contact RaY at ray@yorksj.ac.uk 
Majewicz, Alfred F. \& Pogonowski, Jerzy (1984), "On Categorial Marking in Natural Languages". Lingua Posnaniensis 26, 56-68

Matthews, P[eter] H. (1972), Inflectional Morphology: A Theoretical Study based on Aspects of Latin Verb Conjugation. Cambridge etc.: Cambridge Univ. Press (Cambridge Studies in Linguistics 6)

Matthews, P[eter] H. (1974), Morphology. Cambridge etc.: Cambridge Univ. Press.

Matthews, P[eter] H. (21991), Morphology. Cambridge etc.: Cambridge Univ. Press.

Mel'čuk, Igor' A. (1963), “O 'vnutrennej fleksii' v indoevropejskich i semitskich jazykach". Voprosy jazykoznanija 1963.4, 27-40 [German transl.: "Zur 'inneren Flexion' in den indoeuropäischen und semitischen Sprachen”. In: Mel'čuk, I[gor'] A. (1976), Das Wort: Zwischen Inhalt und Ausdruck. München: Fink (Internationale Bibliothek für allgemeine Linguistik 9), 258-287]

Mel'čuk, Igor' A. (1973), Model' sprjaženija v aljutorskom jazyke. I-II. Moskva: Institut russkogo jazyka AN SSSR (Predvaritel'nye publikacii Problemnoj gruppy po èksperimental'noj i prikladnoj lingvistike 45-46)

Mel'čuk, Igor A. (1982), Towards a Language of Linguistics. München: Fink (Internationale Bibliothek für allgemeine Linguistik 44)

Mel'čuk, Igor A. (1990), "Where and How to State Some Generalizations in Morphology". In: Wiener slawistischer Almanach 25/26 [= Festschrift L'ubomir Ďurovič zum 65. Geburtstag], 299-310

Mel'čuk, Igor A. (1991), "Subtraction in Natural Language". In: Grochowski, Maciej \& Weiss, Dan- iel (eds.), "Words Are Physicians for an Ailing Mind". For Andrzej Bogustawski on the Occasion of His 60th Birthday. München: Sagner (Sagners Slavistische Sammlung 17), 279-293

Mel'čuk, Igor A. (1993), Cours de morphologie générale (theoretique et descriptive), Vol. I: Introduction et Première partie: Le mot. Montréal: Presses de l'Université de Montréal; [Paris]: CNRS

Mel'čuk, Igor A. (1997a), Cours de morphologie générale (theoretique et descriptive), Vol. IV: Cinquième partie: Signes morphologiques. Montréal: Presses de l'Université de Montréal; [Paris]: CNRS Mel'čuk, Igor A. (1997b), "Grammatical Cases, Basic Verbal Construction, and Voice in Maasai: Towards a Better Analysis of the Concepts". In: Dressler, Wolfgang U. \& Prinzhorn, Martin \& Rennison, John R. (eds.), Advances in Morphology. Berlin, New York: de Gruyter (Trends in Linguistics: Studies and Monographs 98), 131-170

Mugdan, Joachim (1977), Flexionsmorphologie und Psycholinguistik. Tübingen: Narr (Tübinger Beiträge zur Linguistik 82)

Nida, Eugene A. ( $\left.{ }^{2} 1949\right)$, Morphology. Ann Arbor: Univ. of Michigan Press [11946]

Reformatskij, Alexandr A. $\left({ }^{4} 1967\right)$, Vvedenie v jazykovedenie. Moskva: Prosveščenie [11947] Moskva: Učpedgiz]

Sapir, Edward (1921), Language: An Introduction to the Study of Speech. New York: Harcourt, Brace Szymanek, Bogdan (1989), Introduction to Morphological Analysis. Warszawa: Państwowe Wydawnictwo Naukowe

Igor Mel'čuk, Montréal (Canada)

\section{Prefixation, suffixation and circumfixation}

\author{
1. Terminology \\ 2. Formal properties \\ 3. Common functions \\ 4. Distribution of affix position \\ 5. Theoretical issues \\ 6. References
}

\section{Terminology}

Prefixation, suffixation and circumfixation are the non-intrusive types of affixation, i.e. those which add affixes to the margins of a lexical base, as opposed to infixation (Art. 55) and transfixation (Art. 56). A prefix is an affix which is bound before the base. A suffix is an affix which is bound after the base. A circumfix is an affix of which one part is bound before, and the other part after, the base. The term affix is also commonly used to refer to "zero" or "empty affixes" (cf. Art. $45)$, which are ignored here.

Although the terms prefix, suffix and circumfix (and their translation equivalents) are the most widely accepted, a variety of other terms have been employed historically and/or are found in contemporary work. In German, Vorsilbe and Nachsilbe are frequently employed, especially by school grammarians, for prefixes and suffixes, respectively. These terms suggest that affixes are always (single) syllables, which is not always the case, even in German (cf. 2). Ending (French désinence, German (Flexions)endung, Russian okončanie) is often used as a synonym for inflec- 
tional suffix, especially for case-marking on nominal elements and person-marking on verbal elements (cf. Pei \& Gaynor 1954 on ending; Dubois et al. 1973 on désinence; Conrad 1985 on Endung; Rozental' \& Telenkova ${ }^{2} 1976$ on okončanie). This usage reflects the Indo-European focus of most earlier linguists (and of many contemporary scholars), who worked with a family of languages in which inflectional functions were commonly marked exclusively by suffixes (cf. 3 ).

Where these special terms for inflectional suffixes are employed, the term suffix and its translation equivalents (Fr. suffixe, Ger. Suffix, Russ. suffiks) are generally used for derivational categories only (although German also makes the distinction Flexionssuffix 'inflectional suffix' and Derivationssuffix or Ableitungssuffix 'derivational suffix'). In this case, Russ. postfiks and Ger. Postfix are used to cover both inflectional "endings" and derivational "suffixes", but Eng. postfix is used only rarely (for example, in Mayan glyph studies). In Chinese, two terms are used for suffix: hòuzhù, meaning 'something attached after' and cíwei, meaning 'word-tail'. Similarly, Japanese uses setsubigo or setsubiji, meaning 'join-tail-word'.

Prebase is an alternative, but rare, English form for prefix (Fr. préfixe, Ger. Präfix, Russ. prefiks) as is Russian pristavka for prefiks. Préverbe is used by some French linguists for verbal (usually valence-changing) prefixes. In Chinese, again, two terms are used: qiánzhuì, meaning 'something attached before' and citóu, meaning 'word-head'. And, again, Japanese uses settogo or settoji, 'joinhead-word'.

Ambifix and confix are used as synonyms for circumfix, although for some scholars ambifix is used to refer to an affix that can appear on either side, rather than both sides, of the root (cf. Malkiel 1978: 145). Similarly, confix has also been proposed as a term for nonintrusive affixes consisting of a single phonological unit, i.e. for prefixes and suffixes, excluding circumfixes (Mel'čuk 1982: 84; cf. Mugdan 1990: 51).

\section{Formal properties}

Unless otherwise indicated, the statistical data in this and subsequent sections come from the GRAMCATS database at the University of New Mexico, which records information on grammatical (inflectional) morphemes from a geneticallybalanced survey of 94 languages (cf. Bybee et al. 1994; Art. 77).
One of the most basic characteristics of nonintrusive suffixes is that they tend to be short; indeed, it seems that they rarely extend beyond a single syllable. The most widely attested phonological shape for prefixes and suffixes (and the elements that make up circumfixes) appears to be a single syllable with a CV sequence, which has been established as the phonologically unmarked (and only universally attested) syllable structure (cf. Jakobson 1941):

(1) (a) Chichewa plural prefix /ma-/, e.g. /bwé:zi/ 'friend', /ma-bwé:zi/ 'friends'

(b) Kiwai iterative suffix - $t i$, e.g. arigi '[to] scratch', arigi-ti '[to] scratch repeatedly'

Beyond this canonical structure, the preferences seem to change depending on position before or after the root: after $\mathrm{CV}$, the next most preferred shape for prefixes appears to be a single consonant, followed again by simple syllables of the form $\mathrm{CVC}, \mathrm{VC}$, and $\mathrm{V}$; bisyllabic prefixes appear to be relatively uncommon.

(2) (a) Maasai negative prefix $m$-, e.g. $a$-rany 'I sing', m-a-rany 'I do not sing'

(b) English privative prefix dis-, e.g. arm, dis-arm

(c) Kekchi 1st person possessive prefix in-, e.g. $c i$ 'dog', in-ci 'my dog'

(d) Huichol locative prefix e-, e.g. ne$p$-e-i-nanai '1.SG.SUBJ-INDIC-another place-3.SG.OBJ-buy(COMPLETIVE) (I bought it in another place)'

It is likely, of course, that data on derivational affix shape preferences will yield different patterns; thus, derivational prefixes of bisyllabic structure, such as Latin mono-, para-, circum-, may be more common than their inflectional counterparts. Such distributional data are, however, currently unavailable, and so further claims would be impressionistic only.

Beyond the preferred CV structure, inflectional suffixes, unlike prefixes, show a continuing preference for full syllables, including monosyllables CVC, VC, V, and bisyllables CVCV, VCV. Much less preferred than in prefix position, but still widely attested, is the single consonant $\mathrm{C}$.

(3) (a) German diminutive -lein, e.g. Kind 'child', Kind-lein 'little child'

(b) Ket plural -an, e.g. am 'mother', aman 'mothers' 
(c) Siberian Yupik possessive - $a$, e.g. anjaq 'boat', anja-a 'his boat'

(d) Malayalam plural -kal, e.g. parawa 'dove', parawa-kal 'doves'

(e) Coos 'kinship' -îni, e.g. sla'atc 'cousin', sla'tc-îni 'mutual cousins'

(f) Siberian Yupik possessive - $n$, e.g. an$j a q$ 'boat', anja- $n$ 'your boat'

Generalising, then, it seems that $\mathrm{CV}$ is the most common shape for inflectional affixes (over a third in the GRAMCATS sample), and that most affixes are monosyllables (around two thirds), but that prefixes show a much stronger tendency to appear as single consonants or pairs of consonants and that suffixes show a greater toleration for bisyllables. Consonant clusters are not common. Tab. 54.1 shows figures from the GRAMCATS sample $(<1$ indicates that the affix is sub-syllabic, i.e. it consists of a single consonant or consonant cluster).

\begin{tabular}{llc}
\hline No. of syllables & Prefix $(\%)$ & Suffix $(\%)$ \\
\hline$<1$ & 17.70 & 6.87 \\
1 & 65.64 & 53.49 \\
2 & 15.02 & 25.72 \\
$3+$ & 1.64 & 3.92 \\
\hline
\end{tabular}

Tab. 54.1: Canonical shape of inflectional affixes

Of monosyllabic prefixes in the sample, $41 \%$ are of CV structure; of suffixes, $27.5 \%$. Affixes of up to four syllables may be identified (e.g. Garo -nabadona 'uncertain future'; cf. Bybee 1985: 179f.), but this seems to be the upper limit, and, in many cases (perhaps including Garo -nabadona), such forms are further analysable (if only diachronically) into strings of two or more separate affixes.

An account of the canonical phonological shape of affixes must also address the issue of phonological strength or formal stability, in terms of degree of allomorphy, susceptibility to reduction or loss, and degree of fusion with the base. One of the most fundamental factors to be taken into account in such an assessment is the diachronic source of affixes as free lexical morphs. Non-intrusive affixes not only tend to be short; they also tend to be phonologically weak, being typically unstressed, and are generally more prone than free grammatical morphemes to assimilate to the base (i.e. to undergo phonologically conditioned allomorphy). They also show more variation from the canonical form in terms of non-phonologically conditioned allomorphy (cf. Bybee et al. 1990: 12, 18). Figures from the GRAMCATS sample (Tab. 54.2) show how free morphs with grammatical functions exhibit greater phonological strength than affixes on these measures.

\begin{tabular}{lll}
\hline & $\begin{array}{l}\text { Phonologically } \\
\text { conditioned } \\
\text { allomorphy }\end{array}$ & $\begin{array}{l}\text { All } \\
\text { allomorphy }\end{array}$ \\
\hline Affixes & 17.7 & 56.0 \\
Free morphs & 6.0 & 28.5 \\
\hline
\end{tabular}

Tab. 54.2: Allomorphy in affixes vs. free grammatical morphs ( $\%$ affixes)

Moreover, it seems that of affixes which exhibit allomorphy, most $(56.3 \%)$ have more than two allomorphs. Clearly, then, affixes tend to be phonologically weaker and formally less stable than free grammatical morphs. Free grammatical morphs, in turn, tend to be phonologically weaker and formally less stable than full lexical morphs, and indeed, it has been suggested that this gradient from free lexical expression to bound grammatical expression reflects a diachronic process, whereby free lexical items progressively lose their formal integrity until they become formally dependent on adjacent items, i.e. they become affixes. The postulation that processes of semantic generalisation and phonological attrition and fusion explain the origins of affixes has a long history (cf. Bopp 1820). It has been proposed that bound morphs, both inflectional as well as derivational, were originally free lexical items which underwent semantic generalisation, and consequently reduction of form, until they fused with habitually contiguous free items, to become prefixes or suffixes (cf. Meillet 1912; Givón 1971; Bybee \& Pagliuca 1985; Hall 1992: 84-111; for the genesis of circumfixes, cf. Greenberg 1980). For example, the English causative suffix - (i)fy, as in purify, simplify (and its cognates in related languages) derives ultimately from Latin facere 'to make', a semantically general free lexical verb. In habitual contiguity with adjectives like purus 'pure' and simplus 'simple', the verb gradually became reanalysed as a bound morpheme on adjective bases to give Latin purificare, simplificare etc. Auxiliary verbs constitute a particularly rich source of inflec- 
tional affixation: In Romance languages, for instance, suffixes marking future have arisen from Late Latin periphrastic forms using $h a-$ beo 'have'. The verb habeo underwent semantic change, becoming progressively more general, from its original full lexical meaning of possession, through modal meaning of obligation, to auxiliary status as tense marker (cf. Art. 145, 156; also, Bybee \& Pagliuca 1985 for a similar analysis of Eng. have). It has been suggested that the most common sources of affixes are words in the syntax which constitute heads of the phrases in which they occur (cf. Givón 1984: 228-237; Hall 1992: 74-77; see also 4).

\section{Common functions}

Most cross-linguistic or typological work has concentrated on affixes expressing inflectional functions, since these, although varying greatly across languages, tend to do so less than derivational functions. Derivational affixes span an astonishing range of modifying functions, from the ubiquitous nominalisers, changing verbs and adjectives to nouns (in a sample of fifty languages, $70 \%$ employ nominalising affixes; cf. Hawkins \& Gilligan 1988: 249) to more idiosyncratic cases like the Gombe Fulani verbal suffix - (i)law, indicating that the action of the verb happens quickly (cf. Comrie 1985: 343). In so-called polysynthetic languages, the affix inventory is particularly rich, and its members are used to express meanings that in most languages would be expressed through free lexical or grammatical morphemes in syntactic phrases (cf. examples from Greenlandic and Nahuatl in Art. 128 and Art. 132).

Generally, in inflectional languages which utilise both prefixes and suffixes, a single grammatical function is expressed either in prefix or suffix position, rather than in both (Sapir 1921: 72). For example, in Bantu languages the person affixes on verbs (for both subject and object) are prefixed and the voice affixes (active and passive) are suffixed (cf. Nida ${ }^{2}$ 1949: 81 ); one is not likely to find languages which express active voice as a prefix and passive voice as a suffix. Exceptions to this pattern do occur, however. Classical Nahuatl, for instance, expresses tense functions in both prefix and suffix positions. Choctaw indicates first person as a suffix and other persons as a prefix (cf. Haas 1946); Chukchi transitive verbs have a subject prefix and an object prefix, but with some subjects a first person singular object is expressed by means of a prefix (cf. Muravyova 1998: 531). In Hebrew, person markers appear in both prefix and suffix position, depending on aspect, while in Chimariko, their position as prefix or suffix is lexically governed, being determined by the verb to which they are added (cf. Sapir 1921: 71).

According to the GRAMCATS database, in which 315 functions ("meaning components" or morphosyntactic properties) were factored out from the meanings expressed by a total of 4819 verbal affixes from 94 languages (cf. Bybee et al. 1994), the inflectional function most typically expressed by affixation on the verb is clearly number (plural and singular), followed by subject, person (1st, 2nd and 3rd), object, tense (past and future), and imperative. The present tense is less generally overtly marked than other tenses. Other functions commonly expressed through affixation are: allative (direction towards), anterior, and the aspectual distinctions continuous, habitual, and immediate; also common are location of speaker, negation, and protasis (if-clause). Tab. 54.3 shows figures from the GRAMCATS database.

\begin{tabular}{lll}
\hline "Meaning component" & No. & $\%$ \\
\hline plural & 308 & 6.39 \\
singular & 296 & 6.14 \\
subject & 287 & 5.95 \\
3rd person & 232 & 4.81 \\
1st person & 226 & 4.69 \\
2nd person & 216 & 4.48 \\
object & 205 & 4.25 \\
past & 168 & 3.49 \\
future & 106 & 2.20 \\
imperative & 100 & 2.07 \\
location of speaker & 83 & 1.72 \\
present & 78 & 1.62 \\
allative & 71 & 1.47 \\
negation & 67 & 1.39 \\
anterior & 64 & 1.33 \\
habitual & 56 & 1.16 \\
protasis (if-clause) & 55 & 1.14 \\
immediate & 54 & 1.12 \\
continuous & 51 & 1.06 \\
\hline TOTAL & 2723 & 56.48 \\
\hline
\end{tabular}

Tab. 54.3: Most typical affix functions on verbs (over 50 occurrences in GRAMCATS database) 
The nineteen functions listed in Tab. 54.3 constitute around $6 \%$ of the total number of functions identified, and yet together account for over half of the affix data. On nouns, number is probably also the most common inflection, but in this case only for marking plurality (singular marking appears to be quite rare; cf. Greenberg ${ }^{2}$ 1966: 94). Affixation is much more common than any other expression type for the plurality function (cf. Dryer 1989: 866); from a survey of 307 languages, $84 \%$ were found to express plurality through an affix on the noun.

There does not seem to be a clear correlation between function and position as prefix or suffix, although some generalisations, at various degrees of robustness, can be made for some functions and for some families. The best attested correlation is in the expression of case functions, which have an overwhelming tendency to be suffixed (cf. Hawkins \& Gilligan 1988: 222). It appears that suffixes marking subject and object are never prefixed, although affixes for other cases are reported to appear in prefix position in a small number of languages, including Zulu, Squamish, Sakao and Temiar (data from Matthew Dryer's database at the State University of New York, Buffalo). Person/ number agreement affixes on verbs have a tendency to be suffixed (cf. Bybee et al. 1990: 9), but a greater proportion of prefixes than of suffixes express this function. Valence marking on the verb is also overwhelmingly suffixed, as is interrogative and imperative. Sentence negation, however, appears to have a tendency to be prefixed (cf. Bybee 1985: 177). Even at the higher level of inflection vs. derivation, universal patterns are elusive, although, again, some regularities emerge in particular languages or families. Indo-European inflection is overwhelmingly suffixed (although Greek has inflectional prefixes), whereas derivation appears in both positions. In contrast, Mayan languages tend to have inflectional prefixes and derivational suffixes. Khmer is predominantly prefixing, but uses its prefixes only to express derivational categories, whereas Bantu's overwhelming use of prefixation is limited to inflection (cf. Sapir 1921: 134). These tendencies are ultimately explicable in terms of word order typology and word order change; since affixes are the bound legacy of earlier free elements, subject to word order rules, their positional tendencies within a family can often be traced to genetically-shared word order regularities (cf. Givón 1971; Dahl 1979; Bybee 1985: 177; Greenberg 1980; Art. 145; see also 4 for other potential explanatory factors).

\section{Distribution of affix position}

It seems that human language makes more use of suffixes than of prefixes (cf. Sapir 1921: 70; Greenberg 21966: 92; Hawkins \& Gilligan 1988). Although there are individual languages which appear to express grammatical functions exclusively or almost exclusively through prefixes, there are many more which employ only suffixes (cf. Sapir 1921: 70; Hawkins \& Gilligan 1988: 228). Exclusively prefixing languages include: Kabyl*, Navaho*, Tiwi*, Temiar*, Khmer, AkanFante*, Yoruba*, Acholi*, Mangbetu*, Palantla, Chinantec*, from six different families (* indicates data on verbal affixes only). Exclusively suffixing languages include: Turkish, Nama, Eskimo, Nootka, Yana, Kui*, Uigur*, Maidu*, Chacobo*, Jivaro*, Gu-Yalanji*, Alyawarra*, and Nimboran*, from eleven different families.

It seems that, cross-linguistically, approximately $70 \%$ of affixes (including individual elements of circumfix pairs) are suffixes as compared with $30 \%$ prefixes (cf. Hawkins \& Gilligan 1988: 236; Bybee et al. 1990: 4f.). Explanations for this distribution have been offered basically from two sources:

(a) psychological processing constraints, based on the assumption that functional pressures (here in the form of the language processing mechanism) have the capacity to influence the form of language, and

(b) the exigencies of diachronic change.

From the point of view of on-line word recognition (viewed as information processing; cf. Art. 163), the root morpheme is the key element and so should optimally occur earlier in the input than less informative bound material (cf. Greenberg 1957: 93; Cutler et al. 1985: 748 f.; Hall 1992: 155f.). Psycholinguistic experimentation has demonstrated the critical importance of the temporal nature of speech in lexical processing, especially in spoken word recognition (cf. Marslen-Wilson 1987), and these findings have been complemented by work which suggests that the beginning portions of words are more informative in lexical processing that the final or 
middle portions (cf. Nooteboom 1981; Cole 1973; Cooper \& Paccia-Cooper 1980; Brown \& McNeill 1966: 329f.). Further evidence suggests that morphologically complex words are decomposed during recognition in at least some cases, especially with inflectional affixes, and with derivational affixes where the structure is part of speakers' morphological competence, i.e. where the combination is transparent and the affix productive (cf. Marslen-Wilson et al. 1994: 27; Hall 1995: 177185). It has been concluded from this evidence that the optimal position for lexically heavy elements (roots) will be before lexically light elements (affixes), giving rise to a preponderance of suffixes.

Other factors which have been suggested to contribute to the psychological explanation are the predictability of the content expressed by affixes and the phonological redundancy of affixes (cf. Greenberg 1957: 93; Cutler et al. 1985: 750f.; Hall 1992: 97-107, 157-161). It has been argued that suffixes tend to induce changes in the root morpheme, whereas prefixes retain their phonological integrity, and on the basis of this it has been suggested that suffixes are made even more predictable, since the root modification presignals the upcoming suffix (cf. Greenberg 1957: 93; Hall 1992: 103). Quantitative studies have, however, cast some doubt on this assumption (cf. Bybee et al. 1990: 19-27). Although there is some experimental support for suffix redundancy (cf. Tyler \& Marslen-Wilson 1986: 749-751), extensive cross-linguistic research would need to be conducted to confirm this possibility.

An alternative view of the cross-linguistic distribution of affixes vs. suffixes is that the predominance of suffixes results from the predominance of postposed free grammatical elements in verb-final languages, which crosslinguistically outnumber verb-initial languages. These free forms generalise semantically and reduce phonologically to become bound as affixes. In an analysis of inflectional morphs on verbs in 71 languages, verbfinal languages showed a strong tendency for bound and unbound morphs expressing grammatical functions to be postposed, whereas verb-initial and verb-medial languages showed more of a balance between post- and preposing (cf. Bybee et al. 1990: 7-18). Preposed grammatical morphs tended to be free in verb-medial languages, but were bound in the other language types. The ex- planation for the suffixing preference derived from these data is that

(a) grammatical morphs at clause boundaries (i.e. in verb-initial and verb-final languages) show a strong tendency to become bound as affixes, whereas grammatical morphs which occur clause-internally (i.e. in verb-medial languages) show a weaker tendency to become bound, and in this case reduction to affix is determined by semantic factors (cf. 5);

(b) verb-final languages greatly outnumber verb-initial languages and grammatical morphs appear more consistently in postposed position.

A second regularity is that there appears to be a partial correlation between the predominant (or exclusive) positioning of affixes (as either prefixes or suffixes) and the dominant order of syntactic head and modifier, particularly in the VP and PP (cf. Hawkins \& Gilligan 1988: 226-231; Art. 118). If the overall skewing in favour of suffixing is discounted, the head/affix correlation clearly emerges. Explanations for this distribution have been offered from

(a) cross-component organising principles for the syntax and morphology (Hawkins \& Gilligan 1988: 226-231) and

(b) the results of diachronic change (Hall 1992: 74-83).

Following much work in theoretical morphology in which principles of phrase syntax have been extended to word syntax (cf. Selkirk 1982; Williams 1981; Scalise 1984; Art. $22,42)$, it has been proposed that in the morphology, the affix is the head of the word, and thus follows the same head-ordering pattern as syntactic elements. Alternatively, it has been argued that the correlation between syntactic heads and modifiers is a historical accident, in that the typical diachronic source for affixes is a free lexical item of head status in the syntax, which becomes bound on its former modifiers (cf. Hall 1992: 75-77; Givón 1971; 1984: 228-237).

Circumfixation is much rarer than suffixation or prefixation in languages, but does appear to occur in a large number of disparate language families, as illustrated in a sampling from a non-systematic survey of grammars and grammatical studies:

(4) Afroasiatic (Amharic, Classical Arabic, Harari, Margi, Tuareg); Australian (Alawa, Worora); Austronesian (Indone- 
sian, Rukai, Samoan, Tagalog, Tondano); Caucasian (Georgian); ChukotkoKamchatkan (Chukchi); Finno-Ugric (Udmurt); Ge-Pano-Carib (Abipon); Hokan (Karok); Indo-European (Germanic: Dutch, German; Iranian: Balochi, Caspian subgroup, Early Modern Persian, Ormuri, Pamir subgroup, Pashto, Talysh); Khoisan (!Kung); Kiwai (Kiwai); Macro-Algonquin (Cheyenne); NigerCongo (Voltaic: Akasele; West Atlantic: Dyola); Oto-Manguean (San Pedro Mixtepec, Zapotec, Amatlan Zapotec); Penutian (Mayan: Kekchi, Mam); Totonacan (Totonac); Uto-Aztecan (Nahuatl)

In certain families, e.g. Indo-European and Afroasiatic, circumfixation is particularly well documented and in a few languages, e.g. Indonesian, circumfixes are used to express a wide variety of functions, including marking of nominalisation, verbalisation, iterative, reciprocal, locative, causative, and stative. In German and Dutch, however, circumfixes are found only sporadically.

\section{Theoretical issues}

One of the major theoretical issues arising in the analysis of affixation to the root is how these affixes interact with each other, i.e. how they are ordered on either side of the root. This problem has been studied from various points of view, and with different goals in mind. Although affixes almost always appear in a fixed order within the word (unlike syntactic constituents in a sentence), the problem of determining the positional classes of an affix inventory is often just as difficult as word order determination, especially with a large inventory, as in polysynthetic languages, where the combinatorial possibilities are multiple. Consequently, considerable effort has been expended on devising systematic procedures for what has been called in this context positional analysis (cf. Nida ${ }^{2} 1949$ : 205-207; Grimes 1967; 1983; Muysken 1986; Elson \& Pickett 1983: 12-16). A typical field practice is to record for each affix (or class of affixes) the numerical position it occupies, counting to the left or right of some reference point, normally the root. Taking the furthest position from the reference point, the set of immediately preceding suffixes or subsequent prefixes is identified. From this set, the affix(es) which occupy the next furthest position from the reference point are determined and the procedure is repeated until all rela- tive orders are established. Proponents of a syntactic approach to morphological analysis argue that positional analysis may be accomplished through the postulation of subcategorization frames (cf. Selkirk 1982: 71-74). Advocates of paradigm functions, in contrast, argue that syntactic operations introducing an affix into a tree structure should be kept distinct from operations which realise an affix in a specific sequential position relative to the root, and thus reject subcategorization explanations (cf. Stump 1992; 1993).

From a theoretical point of view, linguists have been concerned with the question of affix order as determined by ordered rule application (in either a characterisation of our tacit knowledge of language or of grammar as an abstract object). In Lexical Morphology affix order is viewed as a problem of rule-block ordering (cf. Siegel 1979; Allen 1978). In relatively simple affix systems like English, the affix inventory has been claimed to be divisible into classes (also called strata, layers or levels), characterised by their proximity to the root, their liability to undergo certain phonological rules (especially stress rules) and other phenomena. It is argued that affixes at lower levels are introduced by rules applying earlier than those introducing affixes at higher levels. In English, for example, -ify, as in purify is introduced at Level I, whereas -er, as in purifier is introduced at Level II (cf. Chomsky \& Halle 1968; Katamba 1993: 89-153). The fundamental notion is that some morphological processes involve a closer relationship between collocated morphemes than other processes; in the theory, the latter correspond to lower levels and the former to higher levels (for the psychological reality of these levels, cf. Emmorey \& Fromkin 1988: 137-141). The approach has been extended to other languages to a limited extent (cf. Booij \& Rubach 1987; Pulleyblank 1986), but some researchers regard it as unable to account for all the data in certain languages (cf. Aronoff \& Sridhar 1983).

In attempts to identify universal causal factors in determining the proximity of affixes to the root, appeals have been made to principles of iconicity (cf. Art. 30). It has been suggested, for example, that affix order is determined by degree of semantic relevance (cf. Bybee 1985: 33-35). Within non-intrusive affixation, the prediction is that affixes expressing more relevant categories will appear closer to the root in multi-affix strings and show a greater degree of fusion with the root (cf. Art. 39). For example, derivational 
affixes virtually always occur closer to the root than inflectional affixes (cf. Bloomfield 1933: 222; Nida ${ }^{2}$ 1949: 99; Greenberg ${ }^{2} 1966$ : 93) and, within inflection, it has been proposed that more relevant categories appear closer to the stem than less relevant categories (cf. Bybee 1985: 33-35). Thus, affixes expressing aspect tend to appear closer to the verb stem than those expressing subject agreement, and the iconicity hypothesis claims that this is because aspect expresses fundamental properties of the verb meaning, whereas subject agreement refers to an argument of the verb rather than affecting the verb meaning itself. For nouns, it appears that number affixes occur closer to the noun stem than case affixes (cf. Greenberg ${ }^{2} 1966$ : 95), and number expresses significant information about what is referred to by the noun stem, whereas case refers to the entity or entities' role in relation to other entities referred to. In line with this hypothesis, it appears that aspect provokes phonological changes in the stem much more often than number agreement does, and lexically-conditioned allomorphs are attested to a much greater extent for aspect than for number (e.g. in Serbo-Croatian; cf. Bybee 1985: 37). These findings are taken to reflect a greater degree of fusion between verb stem and affix for aspect than for number.

Another explanatory account of affix order, again proposed as a linguistic universal, appeals to syntactic rather than semantic factors, claiming that rule application in morphology and syntax are essentially isomorphic. The "Mirror Principle" makes explicit this claim, stating that "the syntactic ordering known via examination of [...] feeding and bleeding relationships [between syntactic rules] must match the morphological ordering known independently by examining morpheme orders" (Baker 1985: 382). Evidence from a wide range of unrelated languages seems to be compatible with this principle; however, its status is still controversial given the separation of syntax and morphology in many grammatical theories (cf. Art. 22, 34, 36). Furthermore, its compatibility with the historical semantic iconicity account of affix order remains to be explored.

The term circumfixation has been employed to refer to the morphological process introducing a discontinuous affixal unit which surrounds the base (cf. Bergenholtz \& Mugdan 1979: 59; Mel'čuk 1982: 84f.); it has also been used to refer to simultaneous prefixation and suffixation, when the formal, distributional, and/or semantic properties of the elements introduced differ according to whether the elements occur combined around a single base or independently (cf. Bauer 1988 b: 20f.; Anderson 1990: 284f.). In the prototypical case, the elements do not occur outside the combination (the distributional criterion), nor express identifiably independent meanings/functions within the combination (the semantic criterion). Clear cases include:

(5) (a) Georgian comparative/superlative circumfix $u$-...-esi, e.g. lamazi 'beautiful', u-lamaz-esi 'more/most beautiful'

(b) Amatlan Zapotec negative circumfix $n a-\ldots-t$, e.g. top 'to gather', na-top- $t$ 'to not gather'

Many reported cases of circumfixation present problems, however, for these criteria, and might be analysed as defective cases of circumfixes or, simply, as prefix-suffix combinations. For example, it is often difficult to distinguish circumfixation from what has been called parasynthesis (Malkiel 1978: 146), where a prefix and suffix pair obligatorily cooccur but have identifiably separable roles within the combination, as in this example from Spanish:

(6) (a) grande 'large' en-grand-ecer, a-grandar 'to enlarge'

(b) loco 'mad' en-loqu-ecer, a-loc-ar 'to madden'

In these forms the en-la- prefixes mark verbalisation, and -ecer/-ar mark the infinitive. Deadjectival forms such as *en-grand-ar or *a-grand-ecer are not attested. The infinitive forms can stand alone (cf. abast-ar, abastecer '[to] supply' from the noun abasto 'supply'), but the prefixes always derive verbs from adjectives, and so require verbal inflection. In such cases, the suffix could be said to potentiate the prefix (i.e. the presence of the suffix is a necessary condition for the presence of the prefix). So, despite their obligatory co-occurrence in deadjectival verbalisation, a circumfix analysis *en-...-ecer and $* a-\ldots-a r$ would seem unmotivated and the postulation of a linked prefix-suffix pair favoured (cf. Scalise 1984: 147-150 for a similar phenomenon in Italian). An oft-cited case of circumfixation is the German past participle $g e-\ldots-t$, e.g. filmen 'to film', gefilm- $t$ 'filmed'. In this case, the element - $t$ does occur alone on some verbs as the past participle marker (e.g. wiederholen, wiederhol-t; probieren, probier- $t$; passieren, passier- $t$ ), 
and so can be analysed as a suffix; the element ge-, on the other hand, does not occur independently. For the group of verbs which take the circumfix, however, both elements are necessary: neither * ge-film nor * film- $t$ are well-formed past participle forms of the verb filmen (cf. Bauer 1988 a: 22f., 197). Since the distributional criterion is partially compromised for this circumfix, it should be seen as defective. Kekchi presents a problematic case for the semantic criterion, in a form of the 3rd person plural possessor, reported as the circumfix /r-...-e?p/ (cf. Nida 21949: 50f.). The prefix element is identical to one form of the 3 rd person singular ergative marker and nominal possessive marker, and the suffix element is identical to a 3 rd person plural absolutive marker:

(7) (a) /r-otjotj/

'his house'

(b) $/ \mathrm{r}$-ot $\int \mathrm{ot} \int-\mathrm{e} \mathrm{p} /$

(c) /jaj/

(d) /jaf-e?p/

'their house'

'he is sick'

'they are sick'

It is possible to analyse (7b), then, as a combination of possessive prefix plus plural suffix, where the suffix encodes the plurality of the possessor as it does the plurality of the subject in $(7 \mathrm{~d})$ but in this combination does not express absolutive.

Circumfixation is a special case of the expression of a single function (a morpheme) by a combination of several markers (morphs), a phenomenon for which the term synaffix has been suggested (Bauer 1988 b). For example, Pawnee expresses potential modality through two prefixes, kus- and $i$-, which occur to the left and right of the subject prefix respectively (cf. Bybee 1985: 181). In the Kubachi dialect of Dargva, essive and ablative locative case is expressed through pairs of suffixes (cf. Comrie 1981: 210).

A further possibility is that an affix may not be specified for position, i.e. it may appear either as a prefix or a suffix, depending on context (cf. Malkiel 1978: 145). In Afar, for example, the determining context for some affixes is the nature of the onset of the base-form: an affix is realised as a prefix before stems beginning with $[\mathrm{e}, \mathrm{i}, \mathrm{o}, \mathrm{u}]$, e.g. $t$ okm-é '2-eat-PERF (you ate)', but as a suffix after stems beginning with [a] or a consonant, e.g. $y a b$ - $t$-é 'speak-2-IMPERF (you speak)'; $a b$ $t$-é 'do-2-PERF (you did)' (cf. Fulmer 1991). A similar phenomenon appears to occur in Kekchi (cf. Nida ${ }^{2}$ 1949: 42). Finally, affixes may be reduplicated (cf. Art. 57). For example, Yukaghir - $n u$ expresses iteration, whereas -nu-nu expresses intense iteration (cf. Bybee 1985: 150 f.). In Tagalog, elements of circumfixes may also be reduplicated (cf. Schachter \& Otanes 1972).

\section{References}

Allen, Margaret Reece (1978), Morphological Investigations. Ph.D. dissertation, Univ. of Connecticut Anderson, Stephen R. (1990), "Sapir's Approach to Typology and Current Issues in Morphology". In: Dressler, Wolfgang U. \& Luschützky, Hans C. \& Pfeiffer, Oskar E. \& Rennison, John R. (eds.), Contemporary Morphology. Berlin, New York: Mouton de Gruyter (Trends in Linguistics: Studies and Monographs 49), 277-295

Aronoff, Mark \& Sridhar, S[hikaripur] N. (1983), "Morphological Levels in English and Kannada; or Atarizing Reagan". Papers from the Annual Regional Meeting of the Chicago Linguistic Society 19.2, 3-16 [Parasession on the Interplay of Phonology, Morphology, and Syntax]

Baker, Mark (1985), "The Mirror Principle and Morphosyntactic Explanation". Linguistic Inquiry $16,373-415$

Bauer, Laurie (1988 a), Introducing Linguistic Morphology. Edinburgh: Edinburgh Univ. Press

Bauer, Laurie (1988 b), "A Descriptive Gap in Morphology". Yearbook of Morphology 1988, $17-27$

Bergenholtz, Henning \& Mugdan, Joachim (1979), Einführung in die Morphologie. Stuttgart etc.: Kohlhammer (Urban-Taschenbücher 296)

Bloomfield, Leonard (1933), Language. New York: Holt [British edition 1935, London: Allen \& Unwin]

Booij, Geert \& Rubach, Jerzy (1987), "Cyclic versus Postcyclic Rules in Lexical Phonology." Linguistic Inquiry 18, 1-44

Bopp, Franz (1820), "Analytical Comparison of the Sanskrit, Greek, Latin, and Teutonic Languages, Showing the Original Identity of Their Grammatical Structure". Annals of Oriental Literature 1, 1-64 [reprinted 1889 in: Internationale Zeitschrift für Allgemeine Sprachwissenschaft 4 14-60; reprint reproduced in: Bopp, Franz (1974), Analytical Comparison of the Sanskrit, Greek, Latin, and Teutonic Languages, Showing the Original Identity of Their Grammatical Structure, ed. by E. F. K. Koerner. Amsterdam: Benjamins (Amsterdam Classics in Linguistics 3)]

Brown, Roger \& McNeill, David (1966), "The 'Tip of the Tongue' Phenomenon". Journal of Verbal Learning and Verbal Behavior 5, 325-337

Bybee, Joan L. (1985), Morphology: A Study of the Relation between Meaning and Form. Amsterdam, Philadelphia: Benjamins (Typological Studies in Language 9)

Bybee, Joan L. \& Pagliuca, William (1985), "Cross-linguistic Comparison and the Develop- 
ment of Grammatical Meaning”. In: Fisiak, Jacek (ed.), Historical Semantics, Historical Word-formation. Berlin etc.: Mouton (Trends in Linguistics: Studies and Monographs 29), 59-83

Bybee, Joan L. \& Pagliuca, William \& Perkins, Revere D. (1990), "On the Asymmetries in the Affixation of Grammatical Material". In: Croft, William \& Denning, Keith \& Kemmer, Suzanne (eds.), Studies in Typology and Diachrony. Papers Presented to Joseph H. Greenberg on His 75th Birthday. Amsterdam, Philadelphia: Benjamins (Typological Studies in Language 20), 1-42

Bybee, Joan L. \& Perkins, Revere D. \& Pagliuca, William (1994), The Evolution of Grammar: Tense, Aspect and Modality in the Languages of the World. Chicago: Univ. of Chicago Press

Chomsky, Noam \& Halle, Morris (1968), The Sound Pattern of English. New York etc.: Harper \& Row

Cole, Ronald A. (1973), "Listening for Mispronunciations: A Measure of What We Hear During Speech". Perception and Psychophysics 11, 153156

Comrie, Bernard (1981), Languages of the Soviet Union. Cambridge etc.: Cambridge Univ. Press

Comrie, Bernard (1985), "Causative Verb Formation and Other Verb-deriving Morphology". In: Shopen, Timothy (ed.), Language Typology and Syntactic Description, Vol. III: Grammatical Categories and the Lexicon. Cambridge etc.: Cambridge Univ. Press, 309-348

Conrad, Rudi (1985), Lexikon sprarchwissenschaftlicher Termini. Leipzig: Bibliographisches Institut

Cooper, William E. \& Paccia-Cooper, Jeanne (1980), Syntax and Speech. Cambridge/MA, London: Harvard Univ. Press (Cognitive Science Series 3)

Cutler, Anne \& Hawkins, John A. \& Gilligan, Gary (1985), "The Suffixing Preference: A Processing Explanation”. Linguistics 23, 723-758

Dahl, Östen (1979), "Typology of Sentence Negation”. Linguistics 17, 79-106

Dryer, Matthew (1989), "Plural Words". Linguistics $27,865-895$

Dubois, Jean \& Giacomo, Mathée \& Guespin, Louis \& Marcellesi, Christiane \& Marcellesi, JeanBaptiste \& Mevel, Jean-Pierre (1973), Dictionnaire de linguistique. Paris: Larousse

Elson, Benjamin F. \& Pickett, Velma B. (1983), Be ginning Morphology and Syntax. Dallas/TX: Summer Inst. of Linguistics

Emmorey, Karen D. \& Fromkin, Victoria A. (1988), "The Mental Lexicon". In: Newmeyer, Frederick J. (ed.), Linguistics: The Cambridge Survey, Vol. III: Language: Psychological and Biological Aspects. Cambridge etc.: Cambridge Univ. Press, 124-149

Fulmer, S. Lee (1991 [1990]), "Dual-position Affixes in Afar: An Argument for Phonologicallydriven Morphology". Proceedings of the West Coast Conference on Formal Linguistics 9, 189-203
Givón, Talmy (1971), "Historical Syntax and Synchronic Morphology: An Archaeologist's Field Trip". Papers from the Annual Regional Meeting of the Chicago Linguistic Society 7.1, 394-415

Givón, Talmy (1984), Syntax: A Functional-typological Introduction, Vol. I. Amsterdam, Philadelphia: Benjamins

Greenberg, Joseph H. (1957), Essays in Linguistics. Chicago: Univ. of Chicago Press

Greenberg, Joseph H. (1963), "Some Universals of Grammar with Particular Reference to the Order of Meaningful Elements". In: Greenberg, Joseph H. (ed.), Universals of Language. Report of a Conference Held at Dobbs Ferry, New York, April 1315, 1961. Cambridge/MA: MIT Press, 58-90 [21966, 73-113; reprinted in: Greenberg, Joseph H. (1990), On Language: Selected Writings, ed. by Keith Denning \& Suzanne Kemmer. Stanford/CA: Stanford Univ. Press, 40-70]

Greenberg, Joseph H. (1980), "Circumfixes and Typological Change". In: Traugott, Elizabeth Closs \& Labrum, Rebecca \& Shepherd, Susan (eds.), Papers from the 4th International Conference on Historical Linguistics [Stanford 1980]. Amsterdam: Benjamins (Current Issues in Linguistics Theory 14$), 233-241$

Grimes, Joseph E. (1967), "Positional Analysis". Language 43, 437-444

Grimes, Joseph E. (1983), Affix Positions and Cooccurrences: The PARADIGM Program. Dallas/ TX: Summer Inst. of Linguistics (SIL Publications in Linguistics 68)

Haas, Mary (1946), "A Proto-Muskogean Grammar". Language 22, 326-332

Hall, Christopher J. (1992), Morphology and Mind: A Unified Approach to Explanation in Linguistics. London, New York: Routledge

Hall, Christopher J. (1995), "Formal Linguistics and Mental Representation: Psycholinguistic Contributions to the Identification and Explanation of Morphological and Syntactic Competence". Language and Cognitive Processes 10, 169-187

Hawkins, John A. \& Gilligan, Gary (1988), "Prefixing and Suffixing Universals in Relation to Basic Word Order". Lingua 74, 219-259

Jakobson, Roman (1941), Kindersprache, Aphasie und allgemeine Lautgesetze. Uppsala: Almqvist \& Wiksell (Språkvetenskapliga Sällskapets Förhandlingar 1940-1942) [reprinted 1969, Stuttgart: Suhrkamp (edition suhrkamp 330); also in: Jakobson, Roman (1962), Selected Writings, Vol. I: Phonological Studies. 's Gravenhage: Mouton [ $={ }^{2} 1971$ The Hague, Paris: Mouton], 328-401; English transl. 1968: Child Language, Aphasia and Phonological Universals, transl. by Allan R. Keiler. The Hague, Paris: Mouton (Janua Linguarum Series Minor 72)]

Katamba, Francis (1993), Morphology. Basingstoke, London: Macmillan 
Malkiel, Yakov (1978), "Derivational Categories". In: Greenberg, Joseph H. (ed.), Universals of Human Language, Vol. III: Word Structure. Stanford/ CA: Stanford Univ. Press, 125-149

Marslen-Wilson, William D. (1987), "Functional Parallelism in Spoken Word-recognition". Cognition 25, 71-102

Marslen-Wilson, William D. \& Tyler, Lorraine K. \& Waksler, Rachel \& Older, Lynn (1994), "Morphology and Meaning in the English Mental Lexicon". Psychological Review 101, 3-33

Meillet, A[ntoine] (1912), "L'évolution des formes grammaticales". Scientia 12, 384-400 [reprinted in: Meillet, A[ntoine] (1948), Linguistique historique et linguistique générale. Paris: Champion (Collection linguistique 8), 130-148]

Mel'čuk, I[gor'] A. (1982), Towards a Language of Linguistics. München: Fink (Internationale Bibliothek für allgemeine Linguistik 44)

Mugdan, Joachim (1990), "On the History of Linguistic Terminology". In: Niederehe, Hans-Josef \& Koerner, Konrad (eds.), History and Historiography of Linguistics. Papers from the Fourth International Conference on the History of the Language Sciences (ICHoLS IV), Trier, 24-28 August 1987, Vol. I. Amsterdam, Philadelphia: Benjamins (Studies in the History of the Language Sciences 51), 49-61

Muravyova, Irina A. (1998), "Chukchee (Paleo-Siberian)". In: Spencer, Andrew \& Zwicky, Arnold M. (eds.), The Handbook of Morphology. Oxford, Malden/MA: Blackwell, 521-538

Muysken, Pieter (1986), "Approaches to Affix Order”. Linguistics 24, 629-644

Nida, Eugene A. (21949), Morphology. Ann Arbor: Univ. of Michigan Press [ $\left.{ }^{1} 1946\right]$

Nooteboom, Sieb G. (1981), "Lexical Retrieval from Fragments of Spoken Words: Beginnings vs Endings". Journal of Phonetics 9, 407-424
Pei, Mario \& Gaynor, Frank (1954), A Dictionary of Linguistics. New York: Philosophical Library Pulleyblank, Douglas (1986), Tone in Lexical Phonology. Dordrecht, Boston: Reidel (Studies in Natural Language and Linguistic Theory 4)

Rozental', Ditmar E. \& Telenkova, Margarita A. (21976), Slovar'-spravočnik lingvističeskich terminov. Moskva: Prosveščenie

Sapir, Edward (1921), Language: An Introduction to the Study of Speech. New York: Harcourt, Brace Scalise, Sergio (1984), Generative Morphology. Dordrecht, Cinnaminson/NJ: Foris (Studies in Generative Grammar 18)

Schachter, Paul \& Otanes, Fe T. (1972), Tagalog Reference Grammar. Berkeley etc.: Univ. of California Press

Selkirk, Elizabeth O. (1982), The Syntax of Words. Cambridge/MA: MIT Press (Linguistic Inquiry Monographs 7)

Siegel, Dorothy (1979), Topics in English Morphology. New York, London: Garland [orig. 1974, Ph.D. dissertation, Massachusetts Institute of Technology]

Stump, Gregory T. (1992), "On the Theoretical Status of Position Class Restrictions on Inflectional Affixes". Yearbook of Morphology 1991, $211-241$

Stump, Gregory T. (1993), "Position Classes and Morphological Theory". Yearbook of Morphology 1992, 129-180

Tyler, Lorraine K. \& Marslen-Wilson, William (1986), "The Effects of Context on the Recognition of Polymorphemic Words". Journal of Memory and Language 25, 741-752

Williams, Edwin (1981), "On the Notions 'Lexically Related' and 'Head of a Word'”. Linguistic Inquiry 12, 245-274

Christopher J. Hall, Cholula (Mexico)

\section{Infixation}

1. Definition and terminology

2. Formal properties

3. Meanings

4. Distribution in the languages of the world

5. Why does infixation exist?

6. References

\section{Definition and terminology}

An infix is an affix which is positioned inside the base such that the preceding and following portions are not meaningful by

themselves. For instance, the Sundanese word barudak 'children' exemplifies infixation since it is analysable into budak 'child' and -ar- 'plural', with neither $b$ - nor -udak independently meaningful (similarly $s_{\llcorner}$ar are, the plural of sare 'sleep', and $n_{L} a r_{\lrcorner} i i s$, the plural of niis 'cool oneself'). In Chamorro, it is a reduplicated syllable of the base that is infixed, e.g. metgogot 'very strong' from metgot 'strong' (on infixal reduplication, cf. Art. 57). English strong verbs (sing - sang) and internal plurals (foot - feet) can also be de- 